\author{
Merete Føinum \\ Institutt for lcererutdanning og skoleforskning \\ Universitetet i Oslo \\ E-post: merete.foinum@ils.uio.no
}

\title{
Når skolens behov blir viktigere enn formell kompetanse: Hvordan veilede nyutdannede lærere til å undervise i skolefag de ikke har?
}

\begin{abstract}
Sammendrag
Studien undersøker veiledning av nyutdannede lærere ved en norsk ungdomsskole. Artikkelen problematiserer de ekstra krevende arbeidsbetingelsene som disse nye larerne møtte i sitt første år, da de ble satt til å undervise i skolefag de ikke hadde studert. Forskningsspørsmålet er: Hvordan fremstiller nyutdannede ungdomsskolelærere sine opplevelser med å undervise $i$ skolefag de ikke selv er formelt kvalifisert i, og på hvilke måter kan veiledning bidra med støtte? Artikkelen presenterer utdrag fra veiledningssamtaler som eksemplifiserer to nye lareres fremstilling av eget arbeid med elevvurdering når de mangler formell kvalifikasjon $i$ faget. De nyutdannedes perspektiv, og mentorens, fremheves som et samspill gjennom interaksjonsanalyse. Artikkelens teoretiske bidrag er analysebegrepene - «psykologisk-emosjonell mentorstøtte» og «faglig-profesjonell mentorstøtte» - som brukes for å identifisere ulike varianter av mentorstøtte i veiledningssamtaler. Innenfor hovedtypen «faglig-profesjonell mentorstøtte» utdypes distinksjonen videre når det skilles analytisk mellom mentor-bidrag som vektlegger spisset drøfting av skolefag (faglig) og mentor-innspill av pedagogisk eller mer generell didaktisk karakter (profesjonell). Dermed bidrar studien til å vise hvordan ulike kvaliteter i faglig-profesjonell lærerveiledning kan gjenkjennes i praksis. Funnene viser hvor avgjørende det er at mentor har kompetanse i det skolefaget det skal veiledes $i$, såfremt skoler ønsker å tilby nyutdannede læerere spisset veiledning i skolefag. Funnene har implikasjoner for skolelederes/-eieres tilrettelegging av arbeidsforhold og organiseringen av veiledningsstøtte for nyutdannede larere.
\end{abstract}

Nøkkelord: nyutdannede (førsteårs)lærere, mentor(ing), veiledning, undervisningskompetanse, skolefag, ungdomsskolen, lærerutdanning

\begin{abstract}
Research on teachers' professional development establishes the first year of teaching as a vulnerable phase for many newly qualified teachers (NQTs). While existing studies shed light on various challenges of NQTs, few studies pay attention to the strains created when NQTs are put in positions of teaching subjects they are not formally qualified for. This study problematizes implications of such work conditions, asking: How do NQTs bring up and discuss issues of teaching school subjects without formal qualifications, and how can mentors support them? Mentoring of NQTs at a lower secondary school in Norway was observed. The NQTs' perspectives on this matter are displayed by presenting conversation excerpts from mentoring situations. The study demonstrates that while NQTs need both subject specific
\end{abstract}


professional support and psychological-emotional support, the quality of the professional support depends on the mentors' subject qualifications. Knowledge from the study bears implications for choices relating to the work conditions of NQTs and mentor-mentee matching when school leaders and administrators facilitate mentoring support for NQTs.

Keywords: newly qualified teachers (NQTs), mentoring quality, teaching competence, school subjects, teacher education

\section{Innledning}

I Norge skisseres scenariet “fremtidig lærermangel” (Kunnskapsdepartementet [KD], 2008). Forskning fra vestlige land viser at slitasjen på lærere er høy, og at 30-50 \% forlater yrket i løpet av de første 5 årene (Achinstein, 2006; Ingersoll \& Smith 2003, 2004; The Organisation for Economic Co-operation and Development [OECD], 2005). Positive opplevelser med undervisning har stor betydning for begynnende læreres vilje til å fortsette i yrket (Rots, Aelterman, Vlerick \& Vermeulen, 2007). Et aspekt som imidlertid er lite undersøkt, er om nyutdannede opplever det som en belastning å undervise i skolefag de ikke er formelt kvalifisert til gjennom lærerutdanningen, samt hva slags støtte de eventuelt får. Arbeidsgivere i norsk skole har siden 2010 forpliktet seg til å gi systematisk veiledning til nyutdannede lærere (KD, 2014a). Denne studien bidrar med å belyse hvordan slik veiledning kan foregå etter at ordningen kom i gang.

Studien problematiserer en situasjon ved en norsk ungdomsskole der nyutdannede lærere ble satt til å undervise i skolefag de ikke var formelt kvalifisert i. Studien undersøker implikasjonene av denne praksisen, både for de nyutdannede lærerne og veiledningen av disse. Lærerne i studien hadde utdanning som adjunkt eller lektor, og var således kvalifisert for lærerarbeid i ungdomsskolen, og handler ikke om ukvalifisert arbeidskraft i skolen som sådan. Data fra veiledningssamtaler analyseres for å finne ut hvordan undervisningen ble omtalt i veiledningen når de nye lærerne underviste i fag uten å ha fagkvalifikasjonen å støtte seg på. Studien søker å få frem de nyutdannedes perspektiv på saken og hva slags støtte mentoren gav som respons.

Forskningsspørsmålet er: Hvordan fremstiller nyutdannede ungdomsskolelcerere sine opplevelser med å undervise i skolefag de ikke selv er formelt kvalifisert i, og på hvilke måter kan veiledning bidra med støtte? Studien bruker kvalitativ metode for å gi en spisset utforskning av de nyutdannedes opplevelse av egen undervisning, og se på hvordan mentoren støtter de nyutdannede i denne situasjonen. Studien utforsker dette problemområdet og diskuterer implikasjoner for veiledning av nyutdannede, noe som forhåpentligvis vil være fruktbart for videre forskning.

Artikkelen starter med en gjennomgang av forskning som viser hovedtrekk ved nye læreres utfordringer, samt vanlige støttetiltak i det første året som lærer. 
Teoridelen tar opp skolefagets betydning som innholdskomponent i veiledningssamtaler med begynnende lærere. Deretter redegjør jeg for studiens metode og det analytiske begrepsparet «psykologisk-emosjonell mentorstøtte» og «fagligprofesjonell mentorstøtte». I resultatdelen belyser jeg forskningsspørsmålet ved å bruke interaksjonsanalyse til å undersøke data fra veiledningssamtaler. Til slutt drøfter jeg veiledningen i lys av de analytiske begrepene, samt relevant forskning og teori.

\section{Forskning om nyutdannede læreres utfordringer og støtte}

Norsk forskning viser at lærere opplever et gap mellom det de har lært og kravene de blir møtt med i yrket, særlig når det gjelder den teoretiske og relasjonelle kunnskapen de har med seg fra lærerutdanningen (Heggen, 2010). Kunnskapsgapet kan ha ulike forklaringer, men læreryrkets komplekse karakter fremheves som en av årsakene (Heggen 2010; Heggen \& Terum, 2010). Oppstarten på lærerkarrieren kan karakteriseres som et overgangssjokk (Caspersen \& Raaen, 2014).

Både nasjonalt og internasjonalt peker forskning om nye læreres psykologiske stressfaktorer det første året på utfordringer knyttet til identitetskonstruksjon (Flores \& Day, 2006; Schatz-Oppenheimer \& Devir, 2014), sårbarhet (Kelchtermans, 1996), en følelse av profesjonell usikkerhet (Jeffrey \& Woods, 1996; Munthe, 2001, 2003) eller mangel på profesjonell selvtillit (Skaalvik \& Skaalvik, 2007; Tschannen-Moran \& Hoy, 2007), samt utfordringer knyttet til emosjonelle og relasjonelle sider ved lærerarbeidet (Gu \& Day, 2007; Smethem, 2007). Achinstein (2006) forklarer at nye lærere «ofte gis de minst ønskede klasserom og elever, plasseres i skoler der det er vanskelig å skaffe personell, mangler utstyr, blir konstant gransket av ledere, kolleger, foreldre og elever, og ansettes i usikre midlertidige stillinger» (s. 124). Denne og lignende beskrivelser vitner om at mange nye lærere opplever det første året som utfordrende.

Siden det første året anses som en spesielt sårbar periode i læreres utvikling, tar forskere til orde for at nyutdannede bør få mer støtte (Achinstein \& Athanases, 2006; Dangel, 2006). Mentorstøtte blir vurdert som en av de mest effektive komponentene i induksjonsprogrammer, og effekten anses som mest virkningsfull hvis støtten kommer fra en mentor innenfor samme skolefag (Ingersoll \& Smith 2004; Ingersoll \& Strong, 2011; Smith \& Ingersoll 2004). Bjerkholts (2013) studie viser at når mentoren og den nyutdannede læreren har samme fagkompetanse, gir det bedre forutsetninger for å gå i dybden på fagspesifikke og fagdidaktiske aspekter i veiledningen enn det som ellers er mulig å få til. 


\section{Relevansen av kompetanse i ungdomsskolens fag}

Læreres kompetanse i skolefag har blitt et viktig utdanningspolitisk satsningsområde (KD, 2014b; Utdanningsdirektoratet [UDIR], 2015a). Kravene til formalisering av læreres skolefaglige kompetanse har endret seg som et ledd i utdanningsmyndighetenes strategi for å heve utdanningskvaliteten i skolen. Mens en fullført lærerutdanning tidligere var tilstrekkelig for å bli ansatt og undervise i ungdomsskolen, har Stortinget skjerpet kravene til formell undervisningskompetanse i ungdomsskolens fag (KD, 2015). Kravene presiseres i Forskrift til opplæringslov § 14-3 (Lovdata, 2015) og kommer i tillegg til grunnkvalifiseringen som lærer (§ 10-1). Det har altså blitt mer krevende enn før for skoleledere å ansette lærere, fordi formell undervisningskompetanse skal vurderes strengere. For å undervise i fagene norsk, norsk tegnspråk, samisk, engelsk og matematikk i ungdomsskolen må alle lærere ha 60 relevante studiepoeng. UDIR (2015b) estimerer at 29000 grunnskolelærere ikke oppfyller kompetansekravene for å undervise i norsk, engelsk og matematikk. For å undervise i de andre ungdomsskolefagene, med unntak av valgfag, utdanningsvalg og arbeidslivsfag, må lærere som er utdannet etter 1.1.2014 ha 30 relevante studiepoeng. Utdanning og videreutdanning av lærere i fag skolene trenger, er et viktig ansvar for myndighetene og lærerutdanningene fremover.

I lys av denne utviklingen får problemstillinger knyttet til læreres formelle undervisningskvalifikasjoner fornyet aktualitet, og en kan tenke seg at skoler også vil være interessert i å satse på at veiledning av nyutdannede lærere skal være preget av et skolefaglig innhold. Målene med dagens norske veiledningsordning er at nyutdannede lærere skal hjelpes i overgangen mellom utdanningen og yrket det første året, og at veiledning kan bidra til å redusere antall lærere som slutter (KD, 2008). Likevel tyder forskning på at det er store variasjoner i tilbudets utbredelse mellom skoler, kommuner og fylker (Caspersen \& Raaen, 2014; Smith, Ulvik \& Helleve, 2013). Denne artikkelen tar opp hvordan en kan identifisere noen ulike kvaliteter i veiledningen og avklare hvorvidt mentorstøtten er innholdsmessig spisset mot å gi støtte i skolefaget.

Ifølge Utdanningsforbundet (2015) er 3,3 \% av lærerårsverkene i grunnskolen bemannet med ukvalifisert personell. De estimerer at norske grunnskolebarn til sammen har om lag 1,3 millioner skoletimer uten kvalifiserte lærere hvert år, og gir uttrykk for bekymring for situasjonen. TALIS-undersøkelsen (OECD, 2013) kan kaste lys over noen trekk som er spesielle ved den norske situasjonen. Den viser at Norge ligger 4. øverst på lista av 32 land, når det gjelder hvor vanlig det er at lærere underviser i fag de ikke har formell kompetanse i. Dette indikerer at norske lærere mangler formelle kompetanser i fag som skolen etterspør i større grad enn i mange andre OECD-land. Norske tall sier ikke noe spesifikt om hvor mange av de nyutdannede lærerne som underviser i ungdomsskolens fag uten relevante studiepoeng. Det mangler også forskning som belyser hvordan nyutdannede lærere opplever det å undervise uten formelle 
kvalifikasjoner. Min studie supplerer altså eksisterende forskning ved å belyse dette området.

\section{Teori om mentorstøtte}

I internasjonal litteratur om veiledning i læreryrket trekker en rekke forskere opp et analytisk skille mellom psykologisk, emosjonelt eller sosialt orientert støtte, og undervisningsstøtte, som de mener utgjør to ulike orienteringer eller målsettinger for mentorstøtte (Feiman-Nemser, 2001; Gold, 1996; Little 1990; Richter, Kunter, Lüdtke, Klusmann, Anders \& Baumert, 2013). I denne teoriseksjonen viser jeg derfor hvordan jeg har kommet frem til det analytiske begrepsparet psykologisk-emosjonell mentorstøtte og faglig-profesjonell mentorstøtte. Begrepsparet blir senere brukt til å tolke og forstå data fra veiledningssamtaler, og bidrar til å identifisere hva slags støtte mentorene gir til de nyutdannede lærerne.

På den ene siden fremhever altså forskere psykologisk, emosjonelt eller sosialt orientert mentorstøtte til begynnende lærere. Støtten kan handle om å oppmuntre læreren, eller øke, forbedre og bygge selvsikkerhet, selvfølelse og selvtillit (Gold, 1996; Richter mfl., 2013). Dette kan foregå gjennom samtaler og aktiv lytting, teknisk hjelp eller sosial støtte i tilpasningen på arbeidsplassen. Feiman-Nemser (2001) karakteriserer dette som «støtte som får den begynnende læreren til å føle seg bra» (s. 18). Hun assosierer denne typen støtte med konvensjonelle veiledningsmodeller. Ifølge Richter mfl. (2013) kan psykologisk støtte være viktig i det første året, fordi støtten kan redusere stress og gi økt jobbtilfredshet. Støtten peker altså mot hjelp med «den personlige og emosjonelle siden av nyutdannedes profesjonelle utvikling» (Amundsen, 2007, s. 63).

På den andre siden fremheves veiledning som fungerer som undervisningsstøtte (instructional support). Dette forklares av Gold (1996) og Richter mfl. (2013) som en type mentorstøtte som dreier seg om å fremme utviklingen av kunnskaper og ferdigheter som er nødvendige for vellykket undervisning. Ifølge Richter mfl. (2013) kan denne typen støtte handle om hjelp til å planlegge timer, råd om klasseledelse, tilbakemelding på undervisning, hjelp med å vurdere elevers arbeid, osv. Mens Richter mfl. (2013) oppfatter slik støtte som konstruktivistisk, omtaler Feiman-Nemser (2001) dette som profesjonell støtte og mener følgende strategier bidrar til at mentorstøtten blir profesjonell: 1) finn «åpninger», 2) definer problemer, 3) utforsk den begynnende lærerens tenkning, 4) legg merke til tegn på vekst, 5) hold elevfokus, 6) forsterk teoriforståelsen, 7) gi levende eksempler på en persons måte å undervise på, og 8) vis undring over undervisningen. Den profesjonelt innrettede støtten knyttes mot en såkalt læringsfremmende veiledningstilnærming (educative mentoring) som karakteriseres av at mentorstøtten «fremmer en prinsipiell forståelse av undervisning» (s. 18). Med andre ord, i en slik modell må et klart undervisningsutviklende fokus komme i tillegg til den psykologisk-emosjonelle støtten.

I norsk forskning argumenterer Ryeng (2000) og Hoel (2010) for å forsterke fagspesifikke og fagdidaktiske innholdskomponenter i veiledningen. Mens Hoel 
(2010) mener at fag og fagdidaktikk har vært ikke-tema i norsk veiledning, og at oppfølging av nyutdannede dermed har vært for generell, hevder Ryeng (2000) at en dominerende holdning blant kursholdere innen lærerveiledning i en årrekke har vært at veiledningen bør være tverrfaglig. Derved forsvinner fokuset på skolefag. Her følger jeg disse forskernes argumentasjon for å markere skolefagets betydningsfulle rolle i veiledningen av nyutdannede lærere, spesielt fra ungdomsskolen og oppover. Derfor ser jeg i min studie på skolefaglige drøftinger som viktig innhold i veiledningen, spesielt når en av hensiktene er å hjelpe den nyutdannede med å utvikle sin undervisning.

\section{Metode}

I denne studien bruker jeg kvalitative metoder til å analysere veiledningssamtaler mellom en mentor og nyutdannede lærere ved en skole. Rekruttering beskrives først, deretter datainnsamling og analyse.

\section{Rekruttering}

Mentoren i studien ble rekruttert fra et studentkull ved emnet Veiledning og mentoring i læererprofesjonen 2 (VEIL 4020) ved Universitetet i Oslo våren 2011. Sammen med del 1 ga dette studiet 30 studiepoeng innen veiledning. Mentoren, som jeg kaller Olava, er 47 år og adjunkt med fordypning i engelsk. Hun har også geografi og medievitenskap i fagkretsen. Olava har 17 års erfaring som lærer, og underviser i engelsk og samfunnsfag. I tillegg er hun faggruppeleder i disse fagene, og har et par års erfaring med veiledning. Hun hadde ansvar for den praktiske gjennomføringen av veiledningen av nyutdannede lærere ved en 8.-10. trinns skole med omtrent 450 elever, som her blir anonymisert til «Nordavind ungdomsskole». Skolen ligger landlig til i en forstadskommune til en større by på Østlandet. Fire av de syv nyutdannede lærerne ved Nordavind ungdomsskole hadde i 2012/2013 takket ja til å undervise i skolefag de ikke hadde formelle kvalifikasjoner i. Kontakten med rektor og med de nyutdannede lærerne ble opprettet via mentoren.

\section{Datainnsamling}

Feltundersøkelser av veiledning som er «naturlig forekommende» (Silverman, 2011) har vært den viktigste datainnhentingsstrategien. Jeg inntok en rolle som ikke-deltagende observatør, og brukte lydopptaker og notater for å registrere samtaledata. Data fra veiledningssamtaler utgjør primærdataene i studien, mens andre typer kvalitative data (feltarbeidsnotater og dokumenter) blir brukt som supplement der de kan utfylle bildet.

På bakgrunn av den beskrevne situasjonen ved skolen undersøkte jeg først alle data fra veiledningssamtaler der lærere som underviste i skolefag uten 
formell kvalifikasjon deltok. Deretter ble data fra veiledningen med to av disse lærerne valgt ut som særskilt relevant å undersøke på en mer detaljert måte i forbindelse med denne studiens problemstilling. De to nyutdannede lærerne kaller jeg henholdsvis Roar og Andrea:

Roar var 29 år og adjunkt med opprykk. Han har allmennlærerutdanning med matematikk, norsk, kristendom, religion og livssyn (KRL), samt to års fordypning i samfunnsfag/historie. Det første året underviste Roar i religion, livssyn og etikk (RLE), samfunnsfag og engelsk. Han underviste dermed i to av sine fag (KRL og samfunnsfag/historie). I tillegg underviste han i engelsk uten formell kompetanse.

Andrea var 28 år og har master i idrettsvitenskap, med lærerutdanning i kroppsøving, spesialpedagogikk og fransk i fagkretsen. Det første året underviste Andrea i kroppsøving, spansk, og utdanningsvalg. Hun underviste dermed kun i ett av sine fag (kroppsøving). I tillegg underviste hun i spansk uten formell kompetanse.

I løpet av 10 måneders feltarbeid (2012/2013) observerte jeg 18 veiledningssamtaler mellom Olava og disse to lærerne. Jeg gjorde systematiske analyser av lydopptakene fra samtalene ved hjelp av en Grounded Theory-informert analyse (Corbin \& Strauss, 2008; Glaser \& Strauss, 1967). Jeg så spesielt etter sekvenser der innholdet hadde høy relevans for forskningsspørsmålet. Episoder som kunne gi rikholdige bilder av de nyutdannedes opplevelser av eget undervisningsarbeid, og som i tillegg kunne vise hvordan mentoren støttet dem, ble prioritert for nærmere undersøkelse. Episodene ble altså valgt ut ved teoretisk sampling (Corbin \& Strauss, 2008).

I analysen som blir presentert i artikkelen, er noen episoder fra mentorens veiledning av Roar og Andrea valgt ut for nærgående analyse. Roars tilfelle representerer et typisk eksempel på hvordan tre av de fire lærerne som underviste i skolefag uten formelle kvalifikasjoner ved Nordavind ungdomsskole, snakket om undervisningsarbeidet. Andreas tilfelle representerer derimot en atypisk variant. Utdrag fra samtaler med Andrea brukes som eksempel på variasjonen som eksisterte. Til sammen viser de fire utdragene $\mathrm{i}$ analysen hvordan nyutdannede kan oppleve det å undervise i skolefag de ikke har formelle kvalifikasjoner i, på forskjellige måter. For Roar og Andrea gjelder episodene samme type arbeid, men i ulike fag. Det gir mulighet til å sammenligne hvordan de to lærerne fremstiller arbeidet sitt.

Veiledningen med Roar er valgt ut også fordi mentoren har spesielt høy kompetanse i nettopp engelsk, som er det skolefaget Roar underviser i uten formelle kvalifikasjoner. Det er dermed teoretisk interessant å utforske hvordan mentorstøtten arter seg når mentorens skolefaglige kompetanse gir spesielt gode forutsetninger for at den faglig-profesjonelle mentorstøtten kan gis et skolefaglig innhold. Til sammenligning har ikke mentoren kompetanse i spansk, som er det skolefaget som tas opp i drøftingene med Andrea. Det er også teoretisk interessant å se hvordan dette kan påvirke veiledningens innhold. 


\section{Dataanalyse og analysestrategier}

De mest relevante utdragene ble transkribert ved hjelp av en transkripsjonsnøkkel som er laget med utgangspunkt i Jeffersons $(1973,1979)$ transkripsjonssystem (Vedlegg 1). Jeg undersøkte tekstene gjennom interaksjonsanalyse (IA) (Jordan \& Henderson, 1995; Linell, 1998), og valgte å vektlegge samtalenes tematiske innhold fremfor å fokusere på deltakernes kommunikasjonsteknikker. IA-metodikken impliserer en sosiokulturell tilnærming til analyse av samtaledata, der kunnskap og mening forstås som felles konstruert innenfor gitte sosiale settinger (Linell, 1998; Wertsch, 1991). Dette passer godt for å få frem hvordan de to sidene ved veiledning - den nyutdannedes perspektiv og mentorens perspektiv - samspiller når de snakker sammen om de nyutdannedes opplevelser med undervisningen.

Basert på gjennomgangen av de to orienteringene i mentorstøtten som jeg redegjorde for i teoridelen, utviklet jeg det analytiske begrepsparet psykologiskemosjonell mentorstøtte og faglig-profesjonell mentorstøtte. Begrepene brukes for å avklare hva som karakteriserer mentorstøtten. I min bruk av begrepet psykologisk-emosjonell mentorstøtte velger jeg å spisse begrepet noe mer enn det som ble presentert i teoridelen. Jeg vil ikke inkludere teknisk støtte og støtte til sosial tilpasning på arbeidsplassen, fordi jeg er ute etter å begrepsfeste en avgrenset type mentorstøtte som kan identifiseres i data fra veiledningssamtaler.

Jeg forslår videre å bruke begrepet faglig-profesjonell mentorstøtte, hvor «faglig» refererer til skolefaget, og kan inkludere drøftinger av, og støtte i, både vitenskapsfaget og fagdidaktikk i veiledningssamtaler. «Profesjonell» viser til drøftinger av pedagogiske og mer generelt didaktiske saksforhold. Drøftingene handler om læreres profesjonelle arbeid, inkludert undervisningen, men er ikke spesifikke for ett spesielt skolefag. Begge vektleggingene kan finnes innenfor den faglig-profesjonelle mentorstøtten. Det analytiske skillet mellom fag og profesjonell kan bidra til å identifisere hva slags vektlegging mentorstøtten har (eller ikke har). Analytisk kan disse to litt ulike fokus anses som to ulike kvaliteter ved mentorstøtte som gis i undervisningsstøttende veiledning. Begrepsbruken kan derfor bidra til å avklare om mentorstøtten til nyutdannede er mest generell eller om den er mer spesifikt rettet inn mot å veilede i skolefaget.

\section{Resultater}

Som et resultat av at nyutdannede lærere måtte undervise i fag de ikke hadde kvalifisert seg for i lærerutdanningen, ble opplevelser knyttet til denne situasjonen ofte tatt opp i veiledningssamtaler når deres undervisning ble drøftet. Undervisning uten kvalifikasjon ble generelt problematisert som vanskelig. En gjennomgang av samtaledata viste at slik undervisning ble problematisert i 14 av de 18 veiledningssamtalene som mentor Olava gjennomførte med de to nyutdannede lærerne Roar og Andrea. 
Å lage prøver og kriterier for vurdering, sette karakterer, gjennomføre fagsamtaler, vurdere skriftlige prøver, tentamener, stiler og eksamener, samt å vurdere muntlig eller praktisk prøving av elever - alle disse oppgavene knyttet til elevvurdering er eksempler på temaer som ble tatt opp med mentor Olava og problematisert som vanskelige praksiser. Samtaleutdragene som følger, er hentet fra veiledningen, og kan eksemplifisere hvordan Roar og Andrea snakket helt forskjellig om arbeid med elevvurdering når de underviste i skolefag uten formelle kvalifikasjoner.

\section{Roar: Engelskundervisning på 9. trinn}

Mentoren mente at Roar mestret undervisningen i samfunnsfag svært godt. I engelsk erklærte Roar selv at han kunne like lite om engelsk som elevene han underviste. Han problematiserte engelskundervisningen i 9 av de 13 veiledningssamtalene han deltok i, og som denne studien har sett nærmere på. I de to følgende utdragene snakker Roar og mentoren om utfordringene han har med å vurdere elevene i engelsk. Utdragene er hentet fra en individuell veiledningssamtale like før jul.

\section{Utdrag 1: Å vurdere prøver i engelsk}

1. Roar: [...] Hva som (.) på en måte (.) skal korrigeres? Hva som jeg føler er viktig å påpeke. Og så er det liksom det å rette og føre en klar linje på hva de gjør feil. Hva gir et halvt poeng i trekk? Hva gir ett poeng? Er det to poeng? Skal du trekke et halvt, eller et, eller et og et halvt? Ja:h ((sukker)) Jeg synes det ble litt vanskelig

2. Mentor: Det er vanskelig ja

3. Roar: Jeg blir (.) Jeg føler. Det kan godt hende at jeg bommer: At jeg er konsekvent. Men av og til føler jeg at jeg er inkonsekvent. At jeg må gå tilbake og sjekke hva jeg har gitt de andre på samme oppgaven $\uparrow$

4. Mentor: Eh!- Da blir du aldri ferdig (.) Hø:h ((ler))

5. Roar: $\quad[\ldots]$ Og så sitter jeg og klør meg i hodet da. [...] Jeg blir så spent på (.) Når jeg skal dele dem ut da. Og så sitter de ((elevene)) og sammenligner. Og så blir jeg «busted» på noe da $(. .$.

6. Mentor: [...] Det er ikke noen krise. [...] Det er sjelden det påvirker karakteren. [...] $[\ldots]$

7. Mentor: Allikevel [...] Vi må ikke følge våres rette-system slavisk

8. Roar: $\quad[\ldots]$ Jeg må jo ærlig innrømme (.) Jeg skriver jo nesten ingenting. Jeg er jo livredd for å skrive noe særlig på på prøven deres

9. Mentor: ((ler))

10. Roar: Det er karakterer da. Og så får de muntlig tilbakemelding. Og så ser jeg det at i samfunnsfag. Å!- Der skrev jeg plutselig ting $\uparrow$ Ja $\uparrow$ Har det noe med at jeg er trygg å gjøre det kanskje?

11. Mentor: Ja

12. Roar: [...] Men i engelsk så er jeg sånn: Jeg sitter med en penn. Så legger jeg fra meg penna. Så tar jeg frem blyanten. I tilfelle jeg må gå tilbake og stryke ut noe. Så (.) Det er nok en gang engelsken som [...]

13. Mentor: Mm. Du føler deg ikke trygg nok på det. Men som du sier sjøl da, det er jo veldig naturlig. Ikke minst fordi du ikke har undervist i engelsk før. Du har ikke (.) Altså (.) Grunnfag (.) Didaktikk. Du har ikke engelsk. Det er ikke rart at du føler deg utrygg

14. Roar: Nei

Figur 1. Utdrag 1 fra veiledningssamtale med Roar 
Utdrag 1 handler om å vurdere prøver i engelsk. Roar forklarer hvor vanskelig han synes det er å vurdere engelskprøver (1). Han har stadig et behov for å gå tilbake til prøver han har vurdert, for å sjekke hva han har skrevet der (3). Til sammen kan utsagnene indikere at vurderingsprinsippene er uklare (1). Utsagnet «så sitter jeg og klør meg i hodet da» (5) viser sammen med andre utsagn (1, 3, $8,10,12)$ at Roar opplever stor faglig usikkerhet i gjennomføring av elevvurdering i engelsk, og at vurderingsarbeidet tar mye tid. Roars tvil om han vil klare å være konsistent (3) medfører bekymring for at elevene skal «avsløre» vanskelighetene han opplever med å undervise i engelsk (5).

Videre uttrykker Roar at han er «livredd» for å gi skriftlig tilbakemelding på engelskprøver (8), derfor tør han ikke skrive med penn (12). Usikkerheten kan henge sammen med diskusjoner ellers på skolen angående prinsipper for Vurdering for læring (VFL). Der presiseres det at elevvurderingene skal gi elevene informasjon de kan bruke til faglig videreutvikling. Roar antyder at det å gi konstruktive tilbakemeldinger krever en faglig innsikt han ikke har i engelsk. Han opplever at han med letthet klarer å skrive tilbakemeldinger på samfunnsfagsprøvene (10). Dette er en forskjell som både han og mentoren tilskriver at han er tryggere i samfunnsfag enn i engelsk $(10,11,13)$.

Av responsen mentoren gir Roar, ser vi at hun anerkjenner hans opplevelse av utrygghet når det gjelder engelskfaget $(2,4,13)$. Hun forsøker å roe ham ved å si at det ikke er så farlig å gjøre noen feil (6). Hun understreker at det er naturlig å kjenne seg utrygg (13). Vanskene grunngis i det faktum at Roar mangler engelskfaglig kompetanse (13) og støtten hun viser, kan karakteriseres som psykologisk-emosjonell støtte. Når hun i utsagn 7 sier at lærere ikke må følge et rette-system slavisk, kan dette forstås som at faglig skjønn er en ferdighet lærere trenger for å gjennomføre elevvurdering. Sammen med utsagn 13 rammes Roars strev inn til å handle om at det å utvise engelskfaglig skjønn i elevvurderingen, vil være meget krevende uten engelskfaglig kompetanse. Mentors utgangspunkt for å gi Roar psykologisk-emosjonell støtte bunner altså i en forståelse for at Roars undervisningsoppdrag er vanskelig, og begrunnes ved mentorens faglig-profesjonelle vurdering av situasjonen.

Utdrag 2 er hentet fra samme veiledningssamtale. Temaet er at Roars elever skal holde en muntlig presentasjon og utdraget viser hvordan veiledningen brukes til å forberede denne vurderingssituasjonen.

\section{Utdrag 2: Å vurdere muntlig fremføring i engelsk}

1. Mentor: Muntlig vurdering har vi snakket litt om. Torsdag, da skal jeg komme til deg

2. Roar: 9A klasserommet

3. Mentor: Ja og da. Før vi går inn (.) Vi kan faktisk gjøre det nå. At vi ser på noen skjema i forhold til å ha noe foran deg. Sånn at du kan ta en vurdering mens de gjør en fremføring. Og så har man kriteriene foran seg [...] Vi gjør det med en gang $[\ldots]$ 
((Roar går til arbeidsrommet og henter oppgaveteksten elevene har fått og vurderingsskjemaer han har fătt av kolleger. Roar og mentoren setter seg side om side og drøfter vurderingskriterier. Spesielt går de inn på hvor mye det skal ha å si for vurderingen at eleven greier å frigjøre seg fra manus i engelskfremføringen.))

$[\ldots]$

4. Mentor: Ja. Dette ((ser på vurderingsskjemaet)). Jeg tror du kunne gjøre dette lettere for deg selv ved å lage ditt eget vurderingsskjema. Som du kunne dele opp i forhold til innhold og presentasjon. Ikke sant? Jeg tenker ((skisser opp kolonner på arket foran seg)) Og så tenker jeg ((skriver nå kontinuerlig mens hun snakker)) Innhold. Her ((peker)). Har du sagt hva de skal snakke om? Da må du også ha en sjekkliste på items: The origins of the Olympics, History of the Olympics. Okay. Eh ((leser oppgaveteksten stille)). For example: The Norwegian medals? Å:: $\uparrow$ Da kan man snakke om: Språk. Innhold. Intonasjon. Og ordforråd. Grammatikk (.)

5. Roar: Mm ((følger nøye med på at mentor skisserer opp et vurderingsskjema for en engelsk fremføring))

6. Mentor: Det ((peker)) Her er det også veldig viktig med grammatikk. Altså flyten i språket. Altså hvor god eleven er til å kommunisere på engelsk. Man trenger ikke å trekke for grammatiske feil hvis det ikke forstyrrer kommunikasjonen. Tenk på: Får de frem budskapet?

7. Roar: $M m$

8. Mentor: ((Fortsetter å skrive og vise mens hun snakker)) Intonation. Pronounciation. And (.) Grammar!-

Figur 2. Utdrag 2 fra veiledningssamtale med Roar

Utdrag 2 starter med at mentoren og Roar bekrefter en avtale om å gjennomføre vurdering av muntlige engelskfremføringer i Roars klasse sammen (1, 2). Mentoren vil nå arbeide med å forberede klasseromsøkten (3). De ser derfor over oppgaven elevene har fått, og drøfter vurderingskriterier. Når mentoren ser vurderingsskjemaene Roar har fått av noen kolleger, sier hun: «Jeg tror du kunne gjøre dette lettere for deg selv ved å lage ditt eget vurderingsskjema» (4). Olava oppfordrer dermed Roar til å utvikle en egen versjon, noe som kan gi ham bedre forståelse for hva et vurderingsskjema representerer i engelskfaget. Utdraget viser at mentoren arbeider side om side med Roar, tegner kolonner og nedfeller fagspesifikke elementer hun mener bør tas hensyn til i vurderingen av den muntlige presentasjonen $(4,8)$. Ved å forklare hva hun gjør, viser hun Roar tankegangen bak måten hun skreddersyr vurderingsskjemaet på. I utsagn 6 ser vi et eksempel på at mentoren forklarer et fagdidaktisk prinsipp hun mener bør gjelde for vurdering av engelskpresentasjoner på dette nivået. Hun fremhever at selv om grammatikk er viktig, trenger ikke eleven å trekkes for grammatiske feil med mindre det forstyrrer den helhetlige kommunikasjonen og elevens budskap (6).

\section{Oppsummering av Roars case}

I utdrag 1 kommer det frem hvor ukomfortabel Roar er når han arbeider med vurdering i engelsk. Han bruker mye tid, er bekymret for hvorvidt han klarer å være konsekvent, og om han greier å gi elevene konstruktive tilbakemeldinger. Med sin ekspertise i engelsk kunne Olava gi Roar fagspesifikk støtte. Den skolefaglige vinklingen på den faglig-profesjonelle støtten kom spesielt godt frem i samtaleutdrag 2, hvor mentorens innspill var preget av fagspesifikke og presise 
bidrag, med fagdidaktiske vurderinger. En felles vurderingsøkt i Roars klasserom ble planlagt som det neste faglig-profesjonelle oppfølgingstiltaket fra mentoren. Samtalen inngikk i en rekke av samtaler og annen hjelp der Roars engelskundervisning ble tatt opp nesten hver gang, og hvor mentoren spilte på et bredt register av veiledningsteknikker for å gi faglig-profesjonell støtte i engelskfaget.

Mens støtten hovedsakelig tok form av tett faglig-profesjonell oppfølging i engelsk, så vi samtidig islett av psykologisk-emosjonell støtte i denne veiledningssamtalen, slik jeg også fant i andre veiledningssamtaler. De psykologiskemosjonelle innspillene vi så eksempel på her, så likevel ut til å være begrunnet i mentorens faglig-profesjonelle vurdering av vanskegraden i undervisningsoppdraget som Roar strevde med. De to analyserte utdragene er representative for den veiledningen Roar fikk.

\section{Andrea: Spanskundervisning på 10. trinn}

Andrea har fått ansvar for spanskundervisning i en 10. klasse. Selv om hun ikke har formell undervisningskvalifikasjon i spansk, kan hun spansk muntlig.

\section{Utdrag 3: Spansken går greit}

1. Mentor:

2. Andrea:

$\begin{array}{ll}\text { 3. } & \text { Mentor: } \\ \text { 4. } & \text { Andrea: } \\ \text { 5. } & \text { Mentor: } \\ \text { 6. } & \text { Andrea: } \\ \text { 7. } & \text { Mentor: } \\ \text { 8. } & \text { Andrea: } \\ \text { 9. } & \text { Mentor: }\end{array}$

3. Mentor: Me:n (.) Spansken har du i boks $\uparrow$ føler du

4. Andrea: Ja. Eh

5. Mentor: $\quad$ Eller. Ikke i boks - i boks (.) Du har i hvert fall Alexandra som hjelper deg. En

6. Andrea: Ja. Jeg merker at det gjør at jeg er veldig trygg. Og på en måte (.) nå fikk jeg

Ja

Mentor: Supert. Mm.

Fur Utdrag 3 fra veiledningssamtale med Andrea

Utdrag 3 er hentet fra en veiledningssamtale i april mellom Andrea og mentoren. Mentoren spør Andrea om spanskundervisningen, noe hun gjør regelmessig. I dette utdraget ser vi at hun stiller spørsmål om mestring (1), og da responderer Andrea ved å fremheve betydningen av veiledningen som den erfarne spansklæreren Alexandra (også dette navnet er fiktivt) har gitt henne. Alexandras veiledning og tilbakemeldinger gjør at Andrea opplever å mestre spanskundervisningen (2), og at hun føler seg trygg i faget (6). Andrea og Alexandra underviser parallelt, og samarbeider tett om spanskfaget. Mentoren gir psykologisk-emosjonell støtte ved å bekrefte Andreas opplevelse av kontroll (2,3), og hun fremhever også den fagspesifikke veiledningen skolen organiserer i spansk som et positivt tiltak (5). 
Utdrag 4 handler om Andreas spanskundervisning rett før avslutningen av spanskundervisningen på 10. trinn.

\section{Utdrag 4: Hvordan går det med spansken?}

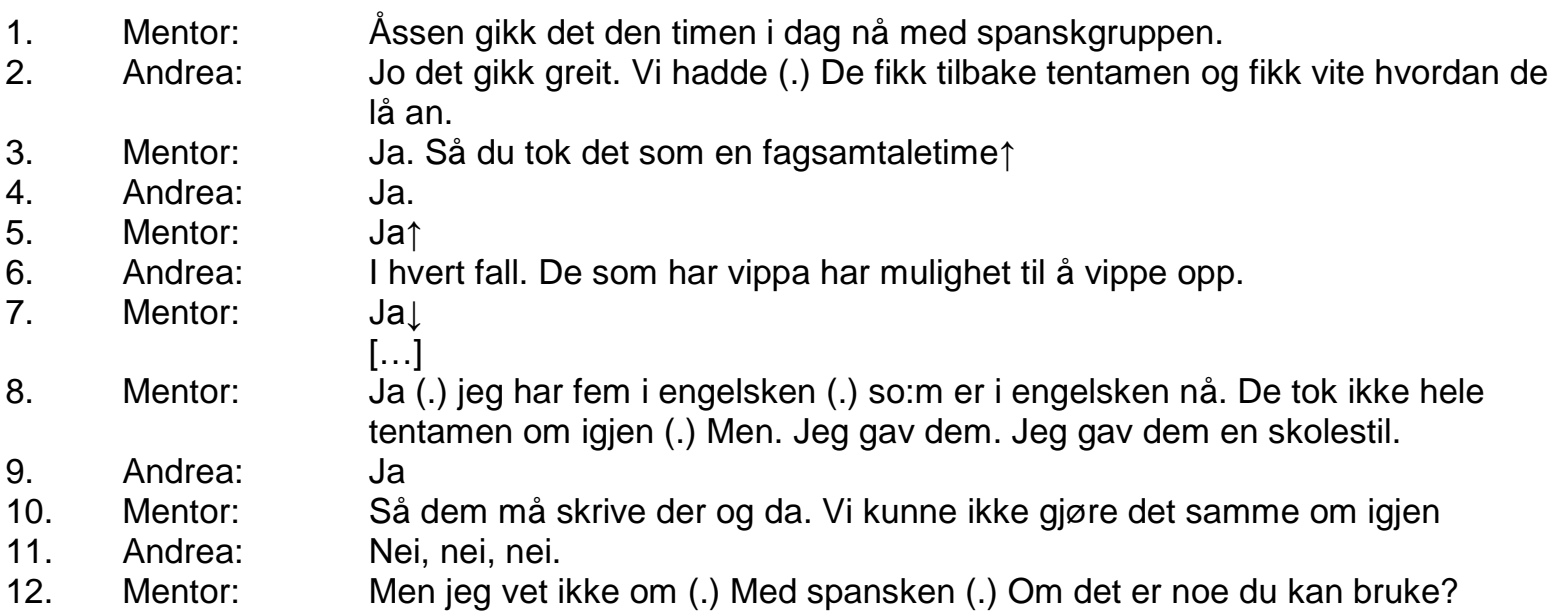

Figur 4. Utdrag 4 fra veiledningssamtale med Andrea

I utdrag 4 ser vi nok en gang at mentoren følger opp Andreas spanskundervisning (1). Andrea rapporterer at hun leverte tilbake tentamen til elevene, og samtidig gjennomførte fagsamtaler $(2,3)$. Dette er en praksis mentoren tidligere har anbefalt. Andrea og mentoren snakker om elever som «vipper» mellom to karakterer (6) og Andrea vil gi elevene en ekstra vurderingsmulighet før hun setter standpunktkarakter (6). Mentoren forteller om en lignende situasjon i sin engelskundervisning, og nevner hva slags oppgaver hun ga sine vippe-elever, kanskje for å gi Andrea ideer til noe hun selv kan gjøre $(8,10)$. Mentoren spør Andrea om «skolestil» kan være en type oppgave hun kan bruke i den planlagte vurderingssituasjonen (12), men lar det være opp til Andrea å vurdere relevansen.

Mentoren har ikke spanskfaglig kompetanse, og kommer heller ikke med fagspesifikke innspill eller vurderinger. Imidlertid bidrar mentoren med generelle pedagogisk-didaktiske ideer når hun snakker ut fra en lignende prøvesituasjon i engelsk, som er et av hennes egne fag. Tipsene mentoren har gitt Andrea tidligere, om gjennomføring av fagsamtaler, er også et eksempel på faglig-profesjonell støtte som ikke er spesielt tilpasset spanskfaget. Denne støtten kan karakteriseres som "profesjonell”, mer enn at den er et bidrag innenfor fag.

\section{Oppsummering av Andreas case}

Andrea ga uttrykk for at hun opplevde mestring og følte seg trygg i spanskundervisningen, selv om hun ikke hadde formell kompetanse. Mentoren bekymret seg for Andreas spanskundervisning, og fulgte opp med tett psykologisk-emosjonell støtte i veiledningen. Spanskfaglig støtte fikk hun fra en annen lærer ved skolen, Alexandra. Siden mentoren ikke hadde spansk i fag- 
kretsen, ble den faglig-profesjonelle støtten hun kunne gi, begrenset til å drøfte pedagogiske og didaktiske problemstillinger på en generell måte. Utdrag 4 viser hvordan mentoren forsøker å finne noen felles referansepunkter mellom engelsk og spansk når de to snakker om vippe-elevene. Vi ser hvordan hun hinter om en oppgave som kanskje kan gi Andrea ideer til en vurderingssituasjon i spansk. Vektleggingen i diskusjonen blir imidlertid ikke fagspesifikk, men holder seg innenfor det generelt profesjonelle. Senere samme vår viste det seg at spanskelevene til Andrea fikk gode karakterer på spanskeksamen. Andreas opplevelse av mestring var altså ikke kun subjektiv.

\section{Diskusjon}

Mens Roar fremstilte arbeid med elevvurdering som spesielt utfordrende når han måtte undervise i et fag han ikke var formelt kvalifisert til, er Andrea et eksempel på at mestringsopplevelsen kan variere.

Andreas eksempel var atypisk, og det er interessant fordi det minner om at man ikke kan ta det for gitt at alle nyutdannede lærere vil oppleve det som like krevende å undervise i skolefag uten de formelle kvalifikasjonene, ei heller at de vil takle utfordringen på samme måte. Eksemplet indikerer at Andrea kunne bruke ferdigheter og kunnskapsmessige ressurser hun hadde med seg inn i lærerjobben når hun skulle undervise i spansk. Hun kunne snakke spansk fra før, og hun hadde formell kompetanse fra et nærliggende språkfag (fransk). Roars eksempel gir et mer representativt bilde av hvor vanskelig flere av de nye lærerne ved denne skolen fremstilte situasjonen når de måtte jobbe med et skolefag de ikke hadde formelle kvalifikasjoner i. Til sammenligning klarte Roar seg meget bra i samfunnsfag, hvor han hadde formell undervisningskompetanse.

De to teoretiske analysebegrepene psykologisk-emosjonell mentorstøtte og faglig-profesjonell mentorstøtte bidro til å avklare om - og når - mentoren ga ulike typer støtte i veiledningsforholdet. Analysene demonstrerte at psykologiskemosjonell støtte er en støtteform som mentoren kan klare å gi uavhengig av hvordan mentor-lærer-parene var satt sammen, fordi slik støtte setter helt andre kompetanser i spill enn den skolefaglige. Data viste at undervisning i skolefag lærerne ikke hadde formelle kvalifikasjoner i, ble problematisert i 14 av 18 veiledningssamtaler, og at slik undervisning ble ansett som vanskelig. Dataene fra studien antyder derfor at situasjonen i seg selv krevde at mentoren fulgte tett opp med psykologisk-emosjonell støtte. Andreas eksempel er også med på å understreke dette, selv om Andrea mestret situasjonen godt.

Når det gjelder den faglig-profesjonelle mentorstøtten finnes det noen utfordringer i det eksisterende teoritilfanget på lærerveiledningsfeltet. Dette handler om at begrepene som er i bruk, er svakt operasjonalisert. Det fremstår som uklart hvordan «undervisningsstøttende» (Richter mfl., 2013) eller 
«profesjonelt» (Feiman-Nemser, 2001) orientert mentorstøtte helt konkret kan se ut i praktiske veiledningssituasjoner. Strategiene Feiman-Nemser (2001) foreslo, kan eksemplifisere dette. De handler om mentorens pedagogiske verktøy, altså om metoden mentoren bruker når hun skaper og medierer et veiledningsinnhold (Orland-Barak, 2014). Strategiene handler dermed ikke så mye om hva innholdet i veiledningen skal bestå av.

Innholdet i veiledningen er ikke gitt - det konstrueres, slik jeg ser det, i interaksjonen mellom en mentor og en eller flere nyutdannede lærere innenfor bestemte sosiokulturelle settinger (Wertsch, 1991). Mentorens ansvar handler, etter min oppfatning, like mye om å kvalitetssikre innholdet i mentorstøtten som å kvalitetssikre metoden for veiledning. Den spissede fagspesifikke og fagdidaktiske mentorstøtten Roar fikk i engelsk, er spesielt interessant i så måte. Det er også interessant sett opp mot diskusjoner som har versert i det norske veiledningsfeltet når det gjelder skolefagets rolle i veiledning av nyutdannede lærere (Hoel, 2010; Ryeng, 2000).

Roars eksempel viser at spisset faglig-profesjonell mentorstøtte med vektlegging av skolefag forekommer ved norske ungdomsskoler, men vi kjenner ikke hyppigheten av det. Tyngdepunktet på fag som kvalitet i den støtten mentoren ga Roar, er ikke en selvfølge. Et slikt faglig fokus forutsetter at mentoren har kompetanse i det aktuelle skolefaget. Andreas tilfelle er et eksempel på at de faglig-profesjonelle utspillene fra mentoren var av en begrenset karakter, og kun av profesjonell art, noe som gir en veiledningskvalitet preget av generelle pedagogiske og didaktiske betraktninger.

Den faglig-profesjonelle mentorstøtten får altså ikke en faglig kvalitet når mentoren ikke selv har skolefaget i sin fagkrets. Dette understreker betydningen av at mentorer kobles med lærere ut fra skolefaglig tilhørighet når mentor-lærerpar (eller -grupper) settes sammen (Little, 1990). Koblingen vil være avgjørende for hva slags kvalitet den faglig-profesjonelle tematiseringen kan få. Ut fra hva Hoel (2010) og Ryeng (2000) har påpekt, kan det se ut som om kobling ut fra skolefag har blitt ignorert når veiledningen av nyutdannede lærere blir organisert, noe Bjerkholts (2013) studie også viser.

Funn og analyser i denne studien peker i retning av at ulike kvaliteter kan gjenkjennes i den mentorstøtten som kan karakteriseres som faglig-profesjonelt undervisningsstøttende. Mens noen drøftinger er av generell karakter (med vekt på «profesjonell»), er andre drøftinger mer spisset mot skolefag (med mer vekt på «faglig»). På ungdomsskolen kan det hevdes at god kvalitet i undervisningsstøttende mentorstøtte bør vurderes ut fra om drøftingene mellom lærer og mentor er av skolefaglig karakter. Med faglig menes her presise drøftinger som gjelder vitenskapsfaglige og fagdidaktiske problemstillinger. Den fagligprofesjonelle kvaliteten i veiledning av nyutdannede lærere foreslås derfor vurdert ut fra om veiledningen innholdsmessig har tyngde når det gjelder drøfting av skolefag eller ikke. 
Mens denne studiens styrke er dypdykket den gjør inn i en spesifikk setting for å utforske fenomener som er lite beskrevet fra før, er det samtidig studiens største svakhet når det gjelder resultatenes overføringsverdi. Studiens verdi kan best vurderes ut fra den empiriske relevansen for praksisfeltet. Det er imidlertid sannsynliggjort innledningsvis, med bakgrunn i TALIS-undersøkelsen, at nyutdannede lærere kan komme i situasjoner hvor de blir satt til å undervise i fag uten formelle kvalifikasjoner også i fremtiden. Likeledes er det sannsynlig at noen mentorer må veilede nyutdannede som er satt i denne typen undervisningssituasjon.

\section{Etterspill}

Høsten 2015 opplyste mentor Olava at disse lærerne fortsatt jobbet ved Nordavind ungdomsskole. Det kan indikere at skolens ordning med mentorstøtte (Olava) og kollegastøtte (Alexandra) ga de nyutdannede lærerne den nødvendige støtten, og at dette veide opp for krevende undervisning og vurdering $\mathrm{i}$ fag de ikke hadde formell kompetanse i. Det at lærerne fortsatt arbeidet ved skolen, kan også tolkes på andre måter. Det kan for eksempel bety at disse nyutdannede lærerne var spesielt robuste, eller i alle fall at de var robuste nok til å tåle de utfordringene de møtte i sitt første arbeidsår. Det at de valgte å bli i jobb som lærere ved akkurat denne skolen, kan også tenkes å henge sammen med andre forhold, som at de trivdes sosialt, var fornøyde med lønnen, at de hadde bosatt seg i området, var i etableringsfaser - eller det kan henge sammen med arbeidsmarkedet. Det kan hende at de nyutdannede vurderte det som positivt for sine respektive CV-er å være i samme jobb over noen år. Hva som motiverte de nye lærerne sterkest til å bli i jobbene sine, er ikke undersøkt i denne studien, og det var heller ikke i undersøkelsens fokus. Samtidig er det et perspektiv det er relevant å forske videre ut fra.

Konklusjon

Arbeidsgiveres betydning for å sikre gode arbeidsvilkår slik at nye lærere ikke slites ut, kan ikke understrekes nok. Veiledningstilbudet ved Nordavind ungdomsskole besto av tett psykologisk-emosjonell mentorstøtte og fagligprofesjonell mentorstøtte av ulike kvaliteter, og kan vurderes som godt. Begge disse hovedtypene støtte så ut til å være betydningsfulle når de ble gitt i kombinasjon. De analytiske begrepene som brukes i denne studien kan bidra til å identifisere når mentorstøtten enten har et skolefaglig fokus eller et profesjonelt fokus, eventuelt begge deler, noe som bør komme i tillegg til psykologisk-emosjonell støtte.

Studien viser at mentorer kan gi faglig-profesjonell støtte med vekting på den skolefaglige kvaliteten under de riktige betingelsene. Det vil si: mentoren må selv ha den aktuelle kompetansen i skolefaget. En forutsetning for at veiled- 
ningen skal kunne være skolefaglig spisset, er at skoleledere og mentorer vektlegger skolefagets betydning når de designer veiledningen som skal gis til skolens nyutdannede lærere. Måten mentorer og nyutdannede lærere kobles på, er her av sentral betydning. Hvis skolene ønsker å legge til rette for at veiledningen skal ha en sterk skolefaglig innholdskvalitet, kan det være et godt utgangspunkt at mentoren og den nyutdannede underviser i samme fag. For å sikre skolefaglig spisset veiledning, kan det være av betydning at skolelederen gjør en samlet vurdering av skolens personalressurser for å finne frem til riktig skolefaglig kobling i veiledningen. Samarbeid med andre skoler om fagspesifikk veiledning kan vurderes for å støtte nyutdannede lærere i skolefaget dersom skolens mentor ikke selv har den skolefaglige kompetansen til å veilede i faget. Samtidig understreker studiens teoretiske analyse at faglig-profesjonell mentorstøtte ser ut til å ha ulik innholdsmessig kvalitet. Dette er noe som bør forskes mer på.

\section{Referanser}

Achinstein, B. (2006). New teacher and mentor political literacy: Reading, navigating and transforming induction contexts. Teachers and Teaching: theory and practice, 12(2), 123-138.

Achinstein, B. \& Athanases, S. Z. (red.) (2006). Mentors in the making: developing new leaders for new teachers. New York: Teachers College Press.

Amundsen, P. (2007): Fra reflekterende student til praktiserende pedagog - Om nyutdannede læreres situasjon og utvikling. I UDIR (2006), Når starten er god. En artikkelsamling om veiledning av nyutdannede lærere i barnehagen, grunnskolen og videregående opplæring (s. 57-67). Oslo: UDIR. Lastet ned 30.11.2015 fra http://www.udir.no/globalassets/upload/skoleutvikling/veiledning-avnyutdannede/art.serie_nett_07.pdf

Bjerkholt, E. (2013) Apning av lukkede rom. En kvalitativ studie av innholdet og dialogene $\mathrm{i}$ veiledningssamtaler mellom nyutdannede lerere og lokale veiledere. Doktoravhandling, Det utdanningsvitenskapelige fakultet, Universitetet i Oslo.

Caspersen, J. \& Raaen, F. D. (2014). Novice teachers and how they cope. Teachers and Teaching: theory and practice, 20(2), 189-211.

Corbin, J. \& Strauss, A. (2008). Basics of qualitative research: Techniques and procedures for developing grounded theory. Thousand Oaks, CA: Sage.

Dangel, J. R. (red.) (2006). Research on Teacher Induction. Teacher Education Yearbook $X I V$. Published in partnership with the Association of Teacher Educators. Oxford: Rowman \& Littlefield Education.

Feiman-Nemser, S. (2001). Helping novices learn to teach: lessons from an exemplary support teacher. Journal of Teacher Education, 52(1), 17-30.

Flores, M. A. \& Day, C. (2006). Contexts which shape and reshape new teachers' identities: A multi-perspective study. Teaching and Teacher Education, 22, 219-232.

Gold, Y. (1996) Beginning teacher support: attrition, mentoring and induction. I J. Sikula (red.) Handbook of research in teacher education (s. 548-594). New York, N.Y: Macmillan. 
Gu, Q. \& Day, C. (2007). Teachers resilience: A necessary condition for effectiveness. Teaching and Teacher Education, 23, 1302-1316.

Glaser, B. G. \& Strauss, A. L. (1967). The Discovery of Grounded Theory: strategies for qualitative research. Chicago: Aldine.

Heggen, K. (2010). Kvalifisering for profesjonsutøving. Sjukepleiar-lærar-sosialarbeidar. Oslo: Abstrakt forlag AS.

Heggen, K. \& Terum, L. I. (2010). Kvalifisering for eit komplekst yrke. I T. L. Hoel, G. Engvik \& B. Hansen (red.), Ny som læerer - sjansespill og samspill (s. 251-269). Trondheim: Tapir Akademisk Forlag.

Hoel, T. L. (2010). Underviser nyutdanna lærarar i fag? I T. L. Hoel, G. Engvik \& B. Hansen (red.), Ny som læerer - sjansespill og samspill (s. 77-98). Trondheim: Tapir akademisk forlag.

Ingersoll. R. M. (2012). Beginner teacher induction: What the data tell us. Phi Delta Kappan, 93(8), 47-51. Lastet ned 1.10.2015 fra http://www.kappanmagazine.org/content/93/8/47

Ingersoll, R. M. \& Smith, T. M. (2003). The Wrong Solution to the Teacher Shortage. Educational Leadership, 60(8), 30-33. Lastet ned 1.10.2015 fra http://citeseerx.ist.psu.edu/viewdoc/download?doi=10.1.1.182.106\&rep=rep1\&type=pdf

Ingersoll, R. M. \& Smith, T. M. (2004). Do Teacher Induction and Mentoring Matter? NASSP Bulletin, 88(638), 28-40.

Ingersoll, R. M. \& Strong, M. (2011). The Impact of Induction and Mentoring Programs for Beginning Teachers: A Critical Review of the Research. Review of Educational Research, 81(2), 201-233.

Jefferson, G. (1973). A case of precision timing in ordinary conversation. Semiotica, 9 (1), 47-96.

Jefferson, G. (1979). A technique for inviting laughter and its subsequent acceptance/ declination. I G. Psathas (red.), Everyday Language (s. 79-96). New York: Irvington.

Jeffrey, B. \& Woods, P. (1996). Feeling Deprofessionalised: the social construction of emotion during an OFSTED inspection, Cambridge Journal of Education, 26(3), 325343.

Jordan, B. \& Henderson, A. (1995). Interaction Analysis: Foundation and Practice. The Journal of the Learning Sciences, 4, 39-103.

Kunnskapsdepartementet [KD]. (2008). Læreren - Rollen og utdanningen. St.m. nr. 11(20082009). Oslo: Forfatter.

Kunnskapsdepartementet [KD]. (2014a). Avtale om kvalitetsutvikling i barnehagen og grunnppleringen. Oslo: Forfatter. Lastet ned 1.10.2015 fra https://www.regjeringen.no/globalassets/upload/kmd/komm/avtale_mellom_kd_og_ks_o m_kvalitetsutvikling_bhg_og_skole.pdf

Kunnskapsdepartementet [KD]. (2014b). Lærerløftet. På lag for kunnskapsskolen. Oslo: Forfatter. Lastet ned 8.12.2015 fra https://www.regjeringen.no/globalassets/upload/kd/vedlegg/planer/kd_strategiskole_web. pdf

Kunnskapsdepartementet [KD]. (2015). Informasjon om endringer i opplæringsloven og privatskoleloven (undervisningskompetanse m.m.). Lastet ned 1.12.2015 fra https://www.regjeringen.no/globalassets/upload/kd/rundskriv/2012/rundskriv_f_02_12_en dringer_opplaeringsloven_privatskoleloven_undervisningskompetanse_mm.pdf

Kelchtermans, G. (1996). Teacher vulnerability: understanding its political and moral roots. Cambridge Journal of Education, 26(3), 307-324.

Linell, P. (1998). Approaching dialogue: Talk, interaction and contexts in dialogical perspectives. Impact: Studies in Language and Society 3. Amsterdam, Philadelphia: John Benjamins Publishing. 
Little, J. W. (1990). The mentor phenomenon and the social organization of teaching. I C. Cazden (red.), Review of Research in Education, 16, 297-351.

Lovdata. (2015). Opplæringsloven / Forskrift til opplæringslova. Lastet ned 1.10.2015 fra https://lovdata.no/dokument/NL/lov/1998-07-17-61 og https://lovdata.no/dokument/SF/forskrift/2006-06-23724/KAPITTEL_16\#KAPITTEL_16

Munthe, E. (2001). Professional uncertainty/certainty: How (un)certain are teachers, what are they (un)certain about, and how is (un)certainty related to age, experience, gender, qualification, and school type? European Journal of Teacher Education, 24, 355-268.

Munthe, E. (2003). Teachers' workplace and professional uncertainty. Teaching and Teacher Education, 19, 801-813.

Organisation for Economic Co-operation and Development [OECD]. (2005). Teachers Matter: Attracting, Developing and Retaining Effective Teachers. Paris: OECD Publishing. Lastet ned 1.10.2015 fra http://www.oecd.org/edu/school/34990905.pdf

Organisation for Economic Co-operation and Development [OECD]. (2013).TALIS 2013 Results. An International Perspective on Teaching and Learning. Lastet ned 14.1.2015 fra OECD Publishing: http://www.keepeek.com/Digital-AssetManagement/oecd/education/talis-2013-results_9789264196261-en\#page1

Orland-Barak, L. (2014). Mediation in mentoring: A synthesis of studies in Teaching and Teacher Education. Teaching and Teacher Education, 44, 180-188.

Richter, D., Kunter, M., Lüdtke, O., Klusman, U., Anders, Y. \& Baumert, J. (2013). How different mentoring approaches affect beginning teachers' development in the first years of practice. Teaching and Teacher Education, 36, 166-177.

Rots, I., Aelterman, A., Vlerick, P. \& Vermeulen, K. (2007). Teacher education, graduates' teaching commitment and entrance into the teaching profession, Teaching and Teacher Education, 23(5), 543-556.

Ryeng, S. (2000). Fagdidaktisk kollegaveiledning i skolen: Faglighet - mulighet eller hindring? I K. Skagen (red.), Kunnskap og handling i pedagogisk veiledning (s. 163-174). Bergen: Fagbokforlaget.

Silverman, D. (2011). Interpreting Qualitative Data. $4^{\text {th }}$ Edition. Washington: Sage.

Schatz-Oppenheimer, O. \& Devir, N. (2014). From ugly duckling to swan: Stories of novice teachers. Teaching and Teacher Education, 37,140-149.

Skaalvik, E. M. \& Skaalvik, S. (2007). Dimensions of teacher self-efficacy and relations with strain factors, perceived collective efficacy, and teacher burnout. Journal of Educational Psychology, 99(3), 611-625.

Smith, T. M. \& Ingersoll, R. M. (2004). What Are the Effects of induction and Mentoring on Beginning Teacher Turnover? American Educational Research Journal, 41(3), 681-714.

Smith, K., Ulvik, M. \& Helleve, I. (2013). Førstereisen. Lœrdom hentet fra nye læereres fortellinger. Oslo: Gyldendal Norsk Forlag.

Smethem, L. (2007). Retention and intention in teaching careers: Will the new generation stay? Teachers and Teaching: theory and Practice, 13(5), 465-480.

Tschannen-Moran, M. \& Hoy, A. W. (2007). The differential antecedents of self-efficacy beliefs of novice and experienced teachers. Teaching and Teacher Education, 23, 944 956.

Utdanningsforbundet (2015). Ukvalifiserte lærere. Alle barn har rett til en kvalifisert lærer! Oslo: Forfatter. Lastet ned 1.10.2015 fra https://www.utdanningsforbundet.no/Hovedmeny/Vi-mener/Ukvalifiserte-larere/

Utdanningsdirektoratet [UDIR]. (2015a). Hvor mange studiepoeng har lærerne i fagene de underviser i? Statistikknotat 05-2014. Oslo: Forfatter. Lastet ned 2.12.2015 fra 
http://www.udir.no/globalassets/upload/statistikk/statistikknotater/statistikknotat_14_04_l aererkompetanse.pdf

Utdanningsdirektoratet [UDIR]. (2015b). Utdanningsspeilet 2015. Tall og analyse av barnehager og grunnopplæringen i Norge. Oslo: Forfatter. Lastet ned 2.12.2015 fra http://utdanningsspeilet.udir.no/2015/wpcontent/uploads/2015/06/Utdanningsspeilet_2015.pdf

Wertsch, J. V. (1991). Voices of the Mind. A Sociocultural Approach to Mediated Action. Cambridge, Massachusetts: Harvard University Press. 


\section{Vedlegg 1}

TRANSKRIPSJONSNØKKEL

\begin{tabular}{|c|c|}
\hline SYMBOL & BETYDNING \\
\hline$[\ldots]$ & $\begin{array}{l}\text { Deler av et utsagn, et utsagn, eller fleire løpende utsagn er tatt ut av } \\
\text { fremstillingen. }\end{array}$ \\
\hline [ ] & Start- og sluttpunkt i overlappende tale \\
\hline$=$ & Pause og påfølgende fortsettelse av en enkelt ytring \\
\hline (\# i sekunder) & Tid, i sekunder, som en pause inne i løpende tale varer \\
\hline (.) & $\begin{array}{l}\text { En kort pause, vanligvis mindre enn } 0.2 \text { sekunder. Flere prikker angir } \\
\text { tilsvarende lengre pause under et sekund }\end{array}$ \\
\hline . eller $\downarrow$ & Fallende tonehøyde eller intonasjon \\
\hline ? eller $\uparrow$ & Stigende tonehøyde eller intonasjon \\
\hline !- & Bråstopp eller avbrudd i ytring \\
\hline$<$ tekst $>$ & Tale som leveres saktere enn vanlig for taleren \\
\hline$>$ tekst $<$ & Tale som leveres raskere enn vanlig for taleren \\
\hline${ }^{\circ}$ tekst ${ }^{\circ}$ & Hvisking, redusert lydnivå, eller stille tale \\
\hline understreking & Taleren legger vekt på eller stresser tale \\
\hline$:::$ & Forlengelse av en lyd \\
\hline (.hhh) & Hørbar innånding \\
\hline$(($ kursivert tekst $))$ & Annotering av ikke-verbal aktivitet \\
\hline $\begin{array}{l}\text { ( ikke-hørbart) } \\
\text { eller ( xxx ) }\end{array}$ & Ikke-hørbar tale \\
\hline
\end{tabular}

